\title{
Compost Enhances Forage Yield and Quality of River Saltbush in Arid Conditions
}

\author{
Jianjian Li ${ }^{1}$, Esmat F. Ali ${ }^{2} \mathbb{D}$, Ali Majrashi ${ }^{2}$, Mamdouh A. Eissa ${ }^{3, * \mathbb{D}}$ and Omer H. M. Ibrahim ${ }^{4,5}$ \\ 1 Institute of Botany, Jiangsu Province and Chinese Academy of Sciences, Nanjing Botanical Garden, \\ Mem. Sun Yat-Sen, Jiangsu, Nanjing 210014, China; lijianjian2015@cnbg.net \\ 2 Department of Biology, College of Science, Taif University, P.O. Box 11099, Taif 21944, Saudi Arabia; \\ a.esmat@tu.edu.sa (E.F.A.); aa.majrashi@tu.edu.sa (A.M.) \\ 3 Department of Soils and Water, Faculty of Agriculture, Assiut University, Assiut 71526, Egypt \\ 4 Department of Arid Land Agriculture, Faculty of Meteorology, Environment and Arid Land Agriculture, \\ King Abdulaziz University, Jeddah 21589, Saudi Arabia; oabrahem@kau.edu.sa \\ 5 Horticulture (Floriculture) Department, Faculty of Agriculture, Assiut University, Assiut 71526, Egypt \\ * Correspondence: mamdouh.eisa@aun.edu.eg
}

check for updates

Citation: Li, J.; Ali, E.F.; Majrashi, A.; Eissa, M.A.; Ibrahim, O.H.M. Compost Enhances Forage Yield and Quality of River Saltbush in Arid Conditions. Agriculture 2021, 11, 595. https://doi.org/10.3390/ agriculture11070595

Received: 19 April 2021

Accepted: 18 June 2021

Published: 27 June 2021

Publisher's Note: MDPI stays neutral with regard to jurisdictional claims in published maps and institutional affiliations.

Copyright: (c) 2021 by the authors. Licensee MDPI, Basel, Switzerland. This article is an open access article distributed under the terms and conditions of the Creative Commons Attribution (CC BY) license (https:// creativecommons.org/licenses/by/ $4.0 /)$.

\begin{abstract}
High temperatures and water scarcity are among the main obstacles to producing fodder in arid regions. Saltbush shrubs are used for livestock in many arid regions, especially in saline conditions, due to their high salt tolerance. The produced forage materials under these saline conditions are often low in quantity and quality. This article presents field studies that were conducted for two growing seasons to evaluate the forage yield and quality of river saltbush (Atriplex amnicola Paul G. Wilson) as a function of compost application. The plants were cultivated in saline soil $\left(15 \mathrm{dS} \mathrm{m}^{-1}\right)$, and compost was added at four rates $\left(0,5,10\right.$, and $\left.15 \mathrm{tha}^{-1}\right)$. River saltbush plant produced 9.23-15.60 $\mathrm{t} \mathrm{ha}^{-1}$ of stems and 4.25-7.20 $\mathrm{t} \mathrm{ha}^{-1}$ of leaves yearly (over all the treatments). The crude protein (CP) ranged between $48-70 \mathrm{~g} \mathrm{~kg}^{-1}$ in the stems and between $160-240 \mathrm{~g} \mathrm{~kg}^{-1}$ in the leaves (over all the treatments). The forage yield, crude protein, dry matter, and mineral contents of the tested plant increased significantly $(p<0.05)$ due to compost addition. The application of 5 , 10 , and $15 \mathrm{t} \mathrm{ha}^{-1}$ of compost reduced the $\mathrm{Na}^{+}$concentrations in the leaves by 14,16 , and $19 \%$ (as means of two years) compared with the control. In the same trend, these rates reduced the oxalate concentrations in the leaves by 38, 30, and 29\% (as means of two years) compared with the control. Our results show that compost application improves the activity of polyphenol oxidase (PPO) and catalase (CAT). Compost reduces the adverse impacts of soil salinity by improving the photosynthesis process and increasing the activity of antioxidant defense. Compost also enhances the growth of river saltbush plants cultivated in saline soils, thus, enhancing their value as animal feed. Halophyte plants can be used to utilize saline soils that are not suitable for traditional production. Compost addition is a good agricultural strategy to increase growth and reduce the negative effects of salts.
\end{abstract}

Keywords: Atriplex; halophytes; saline soils; antioxidant enzymes; nutrients uptake

\section{Introduction}

Saline lands are spread in many areas of the world and may reach 1128 million hectares, and most of these lands are located in arid and semi-arid regions [1,2]. Soil salinity inhibits plant growth through osmotic effects, specific-ion toxicity, and/or shortage and disorders of some nutrients [3]. Saline soils cannot be cultivated with traditional field crops; for example, when wheat (Triticum aestivum) and cowpea (Vigna unguiculata) plant are cultivated in a soil with an ECe $10 \mathrm{dS} \mathrm{m} \mathrm{m}^{-1}$ (ECe is the salinity of the soil saturation extract), their yields are reduced by 50\% [4]. Arid conditions lead to the formation of saline soils that are more suitable for growing halophytic plants to provide the world with animal feed. Halophyte plants are defined as those with the ability to grow and flourish in $\geq 200 \mathrm{mM} \mathrm{NaCl}$ [5]. Among the halophyte flora, river saltbush (Atriplex spp.) has been 
used as promising forage plants for livestock [6]. At higher levels of salinity, it can give high dry matter (15-22 t DM ha $^{-1}$ year $^{-1}$ ), which means great hope in supplying forage for livestock [6-8].

Atriplex spp. has a high content of crude protein and is valuable as animal feed ingredients $[9,10]$. Halophyte plants are promising, due to their potential of being a feed resource, especially in arid regions and poor soils [6]. Traditional forage crops, such as alfalfa and corn, have high nutritional value and yield compared to the halophyte forage $[11,12]$, but these plants have very low ability to grow in saline soils compared to halophyte forages $[7,8,13]$.

Soil organic amendments have high water holding capacity, cation exchange capacity (CEC), chelation ability and are considered as good nutrient resources $[9,14]$. Organic amendments are cost-effective, easy-to-use techniques, environmentally and agronomically sound practice to mitigate soil salinity [2,15]. Compost is commonly used as an organic amendment that can be used in this regard [16]. Compost assists cultivated crops to overcome the negative impacts of soil salinity through improving the soil quality characteristics, such as aeration, permeability, aggregation, nutrients availability and uptake, water holding capacity, activity of soil microbes and enzymes, and reducing the toxic elements uptake [17-19]. Compost has another role in increasing plant tolerance and mitigating salt stress by increasing the activity of antioxidant enzymes and salt tolerance defense $[14,17,20]$.

Despite the high ability of halophyte plants to tolerate salt stress, they lose a large part of their quality and production capacity $[5,21,22]$. The ability of halophyte plants to adapt to salt stress can be used to utilize saline soils that are not suitable for growing traditional crops, but the appropriate agricultural strategies should be used to increase growth and reduce the negative effects of salts. There is little information available about the effect of compost in reducing the negative effects of salinity on the quantity and quality of the fodder yield of the halophytic plants. This study investigates the effect of compost on increasing the yield and quality of the fodder yield of river saltbush plants. The study explores the role of compost in increasing the activity of antioxidant enzymes in river saltbush plants.

\section{Material and Methods}

\subsection{Site Description and Field Experiments}

Twenty-day-old seedlings of Atriplex amnicola Paul G. Wilson were transplanted on 15 May 2016 in a private farm located at Gerga, Sohag, Egypt $\left(26^{\circ} 17^{\prime} 44.4^{\prime \prime} \mathrm{N} 31^{\circ} 46^{\prime} 40.0^{\prime \prime}\right.$ E). Seedlings of $A$. amnicola were achieved from the Center of Desert Agriculture (Assiut University, Assiut, Egypt). The experimental site is characterized by a hot climate in summer and cold in winter without rainfall. The soil of the experimental site was sandy loam soil with $\mathrm{EC}_{\mathrm{e}}$ of $15 \mathrm{dS} \mathrm{m} \mathrm{m}^{-1}$, and according to Chhabra [23], the experimental site was saline soil and classified as Typic Torripsamments [24]. Table 1 shows the properties of the studied soil. The seedlings were cultivated at $3 \times 3 \mathrm{~m}^{2}$ spacing with a plant density of 1000 plant ha ${ }^{-1}$. The experiment consisted of four compost rates, namely, $0,5,10$, and $15 \mathrm{t} \mathrm{ha}^{-1}$. The compost rates were mixed with the topsoil layer $(0-20 \mathrm{~cm})$ before plant cultivation and during the preparation of soil in the first year and the beginning of the second year. After the plant cutting in the first season, we added the compost then mixed it with the soil by hoeing machine. The experimental unit was $100 \mathrm{~m}^{2}$. The experiment was repeated in the same location, and the treatments were applied to the same plots each year. The experiment was arranged in a randomized complete block design (RCBD) with five replicates. The plants were irrigated with groundwater $\left(E C=2.5 \mathrm{dS} \mathrm{m}^{-1}\right)$ by using an adjusted surface irrigation system. The aboveground parts of the plants were cut yearly and divided into leaves and stems. The plants were harvested two times during the experiment period, the first was done during May 2017, and the second was done during May 2018. The plants were harvested when they were one year old from the beginning of cultivation. 
Table 1. Basic properties of the studied soil and compost.

\begin{tabular}{ll}
\hline Properties (Units) & Value \\
\hline Texture & Sandy loam \\
$\mathrm{CaCO}_{3}\left(\mathrm{~g} \mathrm{~kg}^{-1}\right)$ & $52 \pm 4$ \\
$\mathrm{pH}$ & $8.20 \pm 0.07$ \\
Salinity $\left(\mathrm{dS} \mathrm{m}^{-1}\right)$ & $15.07 \pm 0.72$ \\
Organic Carbon $\left(\mathrm{g} \mathrm{kg}^{-1}\right)$ & $3.0 \pm 0.2$ \\
Exchangeable sodium percent & 14 \\
Available N (mg kg & $-1)$ \\
Available P $\left(\right.$ Olsen) $\left(\mathrm{mg} \mathrm{kg}^{-1}\right)$ & $100 \pm 5$ \\
Available K $\left(\mathrm{mg} \mathrm{kg}^{-1}\right)$ & $5.5 \pm 0.2$ \\
\hline
\end{tabular}

\subsection{Soil Characterization}

Composite soil sample $(0-20 \mathrm{~cm})$ was collected randomly from the experimental site before cultivation to assess the physical and chemical characteristics (Table 1). The soil was air-dried and ground to pass through a 2-mm sieve. Particle-size distribution of the soil sample was performed using the pipette method that was described by Burt [25]. Soil $\mathrm{pH}$ was measured using a digital $\mathrm{pH}$ meter in a 1:1 suspension of soil-to-water ratio. The organic matter content of the soil was determined using the dichromate oxidation method as described by Wakley and Black [25]. Total carbonates in the soil were estimated using the calcimeter method and calculated as $\mathrm{CaCO}_{3}$ [25]. The electrical conductivity (ECe) was estimated in soil paste to water extract using the salt bridge method [25]. The total nitrogen, available phosphorus, and potassium were determined according to Burt [25].

\subsection{Plant Analysis}

The plant samples were weighed, cleaned, washed with tap and distilled water, air dried, then dried in an oven at $70{ }^{\circ} \mathrm{C}$ until a constant weight, then ground, and stored for chemical analysis. Plant samples were digested in $\mathrm{H}_{2} \mathrm{SO}_{4}$ and $\mathrm{H}_{2} \mathrm{O}_{2}$ as described by Parkinson and Allen [26], and then analyzed for the different elements: nitrogen (N), phosphorus $(\mathrm{P})$, chloride $(\mathrm{Cl})$, sodium $(\mathrm{Na})$, potassium $(\mathrm{K})$, and calcium $(\mathrm{Ca})$. Phosphorus was measured by spectrophotometer (Unico 2000UV, Unico photometers \& spectrophotometers, Ontario, Canada). Chloride in the digested plant samples was measured by titration with silver nitrate after neutralizing the $\mathrm{pH}$ of plant samples [25]. Sodium and potassium were measured by the flame photometer method (Jenway 7PFP, manufacturer: Jenway, Stafford, UK). The $\mathrm{P}, \mathrm{Na}, \mathrm{K}$, and $\mathrm{Cl}$ concentrations in the plant samples were determined according to Burt [25]. Calcium (Ca) in the digested plant samples was measured by the Inductivity Coupled Plasma Emission Optical Emission Spectrometry (ICP-OES, Thermo iCAP 6000 series, manufacturer: Thermo Scientific, Kleve, Germany). Dry matter (DM), moisture content $(\mathrm{MC})$, organic matter $(\mathrm{OM})$, crude protein $(\mathrm{CP})$, fat content, and crude fiber $(\mathrm{CF})$ in the leaves and stems of river saltbush plants were measured according to animal nutrition and product quality laboratory manual [27]. Organic matter and dry matter were determined by oven drying of the forage material, while the crude protein was determined by measuring the nitrogen content by micro-Kjeldahl distillation unit (Gerhrdit s10Vabodest, Germany). The crude fiber was determined by boiling with $\mathrm{H}_{2} \mathrm{SO}_{4}$ and oven drying at $550{ }^{\circ} \mathrm{C}$ for $3 \mathrm{~h}$. Crude fat was extracted by petrol ether and then determined by the Soxhlet apparatus (Soxtherm S306 A, Gerhardt GmbH, Wiesbaden, Germany). The activity of catalase (CAT) was determined after the extraction by $50 \mathrm{mM}$ potassium phosphate buffer $(\mathrm{pH} 7)$ and $10 \mathrm{mM} \mathrm{H}_{2} \mathrm{O}_{2}$, as described in Chandlee and Scandalios [17,28]. The activity of polyphenol oxidase (PPO) was evaluated after the extraction by $50 \mathrm{mM}$ potassium phosphate buffer ( $\mathrm{pH}$ 7.0) and $40 \mathrm{mM}$ pyrogallol according to Rady [17], and Kumar and Khan [29]. The activity of peroxidase (POX) was determined after the extraction by $50 \mathrm{mM}$ potassium phosphate buffer (pH 7.0) and $40 \mathrm{mM}$ pyrogallol and $1 \mathrm{mM} \mathrm{H}_{2} \mathrm{O}_{2}$ [17,29]. SPAD 502 plus (Konica Minolta, Inc., Tokyo, Japan) was used to measure the chlorophylls in the leaves of 
river saltbush. Oxalates were extracted from the oven-dried leaves by $0.25 \mathrm{~N} \mathrm{HCl}$ and then titrated by $0.02 \mathrm{~N} \mathrm{KMnO}_{4}$, as described in Naik et al. [30].

\subsection{Compost Characterization}

Compost was made from chicken feces and corn wastes $(2: 1 w / w)$. Table 2 shows the properties of the compost used in the current study. Organic matter in compost was measured by the loss-on-ignition method [31]. Dried compost samples (2.0 g) were digested with $\mathrm{H}_{2} \mathrm{O}_{2}$ and $\mathrm{H}_{2} \mathrm{SO}_{4}$ as described in the plant analysis section. The total $\mathrm{N}, \mathrm{P}$, and $\mathrm{K}$ concentrations were measured in the digest extract by the same methods in the plant analysis section. The $\mathrm{pH}$ of compost was evaluated in a 1:5 suspension with a $\mathrm{pH}$ meter, and the electrical conductivity (EC) of the 1:5 extract was determined with an EC meter [25].

Table 2. Basic properties of the studied compost.

\begin{tabular}{cccccc}
\hline pH & $\begin{array}{c}\text { Salinity } \\
\left(\mathbf{d S ~ m}^{-\mathbf{1}}\right)\end{array}$ & $\begin{array}{c}\text { Organic Carbon } \\
\left(\mathrm{g} \mathrm{kg}^{-\mathbf{1}}\right)\end{array}$ & $\begin{array}{c}\mathbf{N} \\
\left(\mathrm{g} \mathrm{kg}^{-\mathbf{1}}\right)\end{array}$ & $\begin{array}{c}\mathbf{P} \\
\left(\mathrm{g} \mathrm{kg}^{-\mathbf{1}}\right)\end{array}$ & $\begin{array}{c}\mathbf{K} \\
\left(\mathbf{g ~ k g}^{-\mathbf{1}}\right)\end{array}$ \\
\hline $8.22 \pm 0.1$ & $5.25 \pm 0.3$ & $240 \pm 12$ & $20 \pm 2$ & $15.70 \pm 2.3$ & $35 \pm 3$ \\
\hline
\end{tabular}

\subsection{Data Analysis}

The obtained results were checked by Shapiro-Wilk test for normality. The Analysis of Variance (ANOVA) was used to test the significance of differences between the treatments. The collected data were statistically analyzed by using the MSTAT computer program (MSTAT-C, Michigan State University, Michigan, USA) [32]. Means were compared using Duncan multiple range tests at a 5\% level of probability. All data in tables and figures are means ( \pm standard deviation) of five replicates.

\section{Results}

\subsection{Effects of Compost Addition on the Mineral Content of River Saltbush}

Compost addition significantly increased the concentrations of N, P, and $\mathrm{K}$ in the leaves of river saltbush in the first and second years (Table 3). Sodium (Na) concentrations in leaves tissues of river saltbush plants were reduced significantly due to compost addition. The addition of 5,10 , and $15 \mathrm{tha}^{-1}$ of compost $\left(\mathrm{COM}_{5}, \mathrm{COM}_{10}\right.$, and $\left.\mathrm{COM}_{15}\right)$ reduced $\mathrm{Na}$ concentrations in the leaves by 13,15 , and $20 \%$ in the first year, while these decreases were 14,16 , and $18 \%$ in the second year. Nitrogen, $\mathrm{P}$, and $\mathrm{K}$ increased significantly due to compost addition. $\mathrm{COM}_{5}, \mathrm{COM}_{10}$, and $\mathrm{COM}_{15}$ increased $\mathrm{N}$ in the leaves by 46,30 , and $23 \%$ in the first year by 16,19 , and $9 \%$ in the second year. $\mathrm{COM}_{5}, \mathrm{COM}_{10}$, and $\mathrm{COM}_{15}$ increased $\mathrm{K}$ in the leaves by 15,30 , and $35 \%$ in the first year, while these increases were 20,25 , and $35 \%$ in the second year. $\mathrm{COM}_{10}$ and $\mathrm{COM}_{15}$ increased $\mathrm{P}$ in the leaves by 45 and $40 \%$ in the first year and by 27 and $32 \%$ in the second year.

\subsection{Effect of Compost on Some Biochemical Compounds of Leaves}

Chlorophyll in river saltbush responded significantly to the addition of compost (Figure 1). The addition of 5, 10, and $15 \mathrm{tha}^{-1}$ of compost $\left(\mathrm{COM}_{5}, \mathrm{COM}_{10}\right.$, and $\left.\mathrm{COM}_{15}\right)$ elevated the chlorophyll in the leaves by 37,27 , and $33 \%$ over the non-amended soil in the first year, while these increases were 46,50 , and $43 \%$ in the second year. Compost significantly reduced the oxalate content in the leaves of river saltbush plants (Figure 1). $\mathrm{COM}_{5}, \mathrm{COM}_{10}$, and $\mathrm{COM}_{15}$ decreased the oxalic acid by 41,24 , and $26 \%$ compared with the control in the first year and by 34,36 , and $32 \%$ in the second year. 
Table 3. Effect of compost treatments on the mineral content of leaves and stems of river saltbush plants $\left(\mathrm{g} \mathrm{kg}^{-1}\right)$.

\begin{tabular}{|c|c|c|c|c|c|c|c|c|c|c|c|c|}
\hline & \multicolumn{6}{|c|}{2017} & \multicolumn{6}{|c|}{2018} \\
\hline & $\mathrm{Na}$ & K & $\mathrm{Cl}$ & $\mathbf{P}$ & $\mathrm{Ca}$ & $\mathbf{N}$ & $\mathrm{Na}$ & K & $\mathrm{Cl}$ & $\mathbf{P}$ & $\mathrm{Ca}$ & $\mathrm{N}$ \\
\hline & \multicolumn{12}{|c|}{ Leaves } \\
\hline Control & $40 \pm 2.1^{\mathrm{a}}$ & $20 \pm 1.1 \mathrm{~b}$ & $35 \pm 1.3^{\mathrm{a}}$ & $2.0 \pm 0.11 \mathrm{~b}$ & $9 \pm 0.4^{\mathrm{a}}$ & $26 \pm 1.05 \mathrm{~b}$ & $44 \pm 2.2^{\mathrm{a}}$ & $20 \pm 1.0^{b}$ & $32 \pm 1.1^{\mathrm{a}}$ & $2.2 \pm 0.18^{b}$ & $4.8 \pm 0.5^{\mathrm{a}}$ & $32 \pm 1.03 \mathrm{~b}$ \\
\hline $\mathrm{COM}_{5}$ & $35 \pm 1.5^{b}$ & $23 \pm 0.8^{b}$ & $33 \pm 1.7^{a}$ & $2.2 \pm 0.14^{b}$ & $4.8 \pm 0.3^{a}$ & $35 \pm 2.07 \mathrm{a}$ & $38 \pm 1.6^{\mathrm{b}}$ & $24 \pm 0.7 \mathrm{a}$ & $28 \pm 1.6^{a}$ & $2.1 \pm 0.16^{b}$ & $4.7 \pm 0.4^{\mathrm{a}}$ & $37 \pm 1.06^{a}$ \\
\hline $\mathrm{COM}_{10}$ & $34 \pm 2.5^{b}$ & $26 \pm 1.2^{\mathrm{a}}$ & $33 \pm 1.8^{\mathrm{a}}$ & $2.9 \pm 0.17 \mathrm{a}$ & $4.9 \pm 0.2^{\mathrm{a}}$ & $34 \pm 1.07^{\mathrm{a}}$ & $35 \pm 2.2^{b}$ & $25 \pm 1.3^{\mathrm{a}}$ & $30 \pm 1.7^{\mathrm{a}}$ & $2.8 \pm 0.16^{a}$ & $4.8 \pm 0.2^{\mathrm{a}}$ & $38 \pm 1.07^{a}$ \\
\hline $\mathrm{COM}_{15}$ & $32 \pm 1.8^{\mathrm{b}}$ & $27 \pm 1.3^{a}$ & $34 \pm 2.0^{\mathrm{a}}$ & $2.8 \pm 0.18 \mathrm{a}$ & $5.0 \pm 0.2^{a}$ & $32 \pm 1.04 \mathrm{a}$ & $36 \pm 1.2^{b}$ & $27 \pm 1.4^{\mathrm{a}}$ & $31 \pm 2.1^{\mathrm{a}}$ & $2.9 \pm 0.17 \mathrm{a}$ & $5.1 \pm 0.3^{a}$ & $35 \pm 1.05^{a}$ \\
\hline $\mathrm{F}_{\mathrm{t}}$ & $*$ & $*$ & ns & $*$ & ns & $*$ & & & & & & \\
\hline $\mathrm{F}_{\mathrm{y}}$ & ns & ns & ns & ns & ns & ns & & & & & & \\
\hline \multirow[t]{2}{*}{$F_{y \times t}$} & * & ns & * & ns & ns & ** & & & & & & \\
\hline & \multicolumn{12}{|c|}{ Stems } \\
\hline Control & $15 \pm 0.5^{\mathrm{a}}$ & $11 \pm 0.4^{\mathrm{a}}$ & $13 \pm 0.7^{\mathrm{a}}$ & $1.1 \pm 0.14^{\mathrm{a}}$ & $1.9 \pm 0.1^{\mathrm{a}}$ & $8.0 \pm 0.04^{\mathrm{a}}$ & $15 \pm 0.4^{\mathrm{a}}$ & $13 \pm 0.5^{\mathrm{a}}$ & $12 \pm 0.6^{\mathrm{a}}$ & $1.2 \pm 0.10^{a}$ & $1.8 \pm 0.1^{\mathrm{a}}$ & $9.6 \pm 0.03 \mathrm{a}$ \\
\hline $\mathrm{COM}_{5}$ & $15 \pm 0.7 \mathrm{a}$ & $10 \pm 0.7^{\mathrm{a}}$ & $13 \pm 0.8 \mathrm{a}$ & $1.0 \pm 0.15 \mathrm{a}$ & $1.8 \pm 0.1^{\mathrm{a}}$ & $8.0 \pm 0.04 \mathrm{a}$ & $13 \pm 0.7 \mathrm{a}$ & $11 \pm 0.7 \mathrm{a}$ & $13 \pm 0.8^{\mathrm{a}}$ & $1.1 \pm 0.12 \mathrm{a}$ & $1.7 \pm 0.1 \mathrm{a}$ & $11.2 \pm 0.04 \mathrm{a}$ \\
\hline $\mathrm{COM}_{10}^{5}$ & $16 \pm 0.4^{\mathrm{a}}$ & $12 \pm 0.5^{a}$ & $10 \pm 0.6^{\mathrm{a}}$ & $0.9 \pm 0.08$ a & $1.8 \pm 0.1^{\mathrm{a}}$ & $7.7 \pm 0.05 \mathrm{a}$ & $14 \pm 0.3^{\mathrm{a}}$ & $12 \pm 0.6^{\mathrm{a}}$ & $10 \pm 0.7^{\mathrm{a}}$ & $0.8 \pm 0.08 \mathrm{a}$ & $1.8 \pm 0.1^{\mathrm{a}}$ & $8.0 \pm 0.06^{\mathrm{a}}$ \\
\hline $\mathrm{COM}_{15}$ & $14 \pm 0.4^{\mathrm{a}}$ & $10 \pm 0.5^{\mathrm{a}}$ & $9 \pm 0.4^{\mathrm{a}}$ & $1.0 \pm 0.11^{\mathrm{a}}$ & $1.9 \pm 0.1^{\mathrm{a}}$ & $8.0 \pm 0.03^{\mathrm{a}}$ & $12 \pm 0.5^{\mathrm{a}}$ & $11 \pm 0.6^{\mathrm{a}}$ & $11 \pm 0.6^{\mathrm{a}}$ & $1.1 \pm 0.12^{\mathrm{a}}$ & $1.8 \pm 0.1^{\mathrm{a}}$ & $11.2 \pm 0.03 \mathrm{a}$ \\
\hline $\mathrm{F}_{\mathrm{t}}$ & ns & ns & * & ns & $\mathrm{ns}$ & ns & & & & & & \\
\hline $\mathrm{Fy}_{\mathrm{c}}$ & ns & ns & ns & ns & ns & ns & & & & & & \\
\hline$F_{y \times t}$ & ns & ** & ns & * & * & ns & & & & & & \\
\hline
\end{tabular}

$\mathrm{COM}_{5}=5 \mathrm{t}$ of compost ha ${ }^{-1}, \mathrm{COM}_{10}=10 \mathrm{t}$ of compost ha ${ }^{-1}$, and $\mathrm{COM}_{15}=15 \mathrm{t}$ of compost ha ${ }^{-1} \cdot{ }^{*} p<0.05,{ }^{* *} p<0.01$, ns: non-significant. Means $( \pm \mathrm{SD})$ denoted by the same letter refers to non-significant differences based on Duncan's test at $p<0.05$. $\mathrm{F}_{\mathrm{t}}, \mathrm{F}_{\mathrm{y}}$, and $\mathrm{F}_{\mathrm{y} \times \mathrm{t}}$ refer to the $F$ value of the treatments, years, and the interaction of treatments and years.
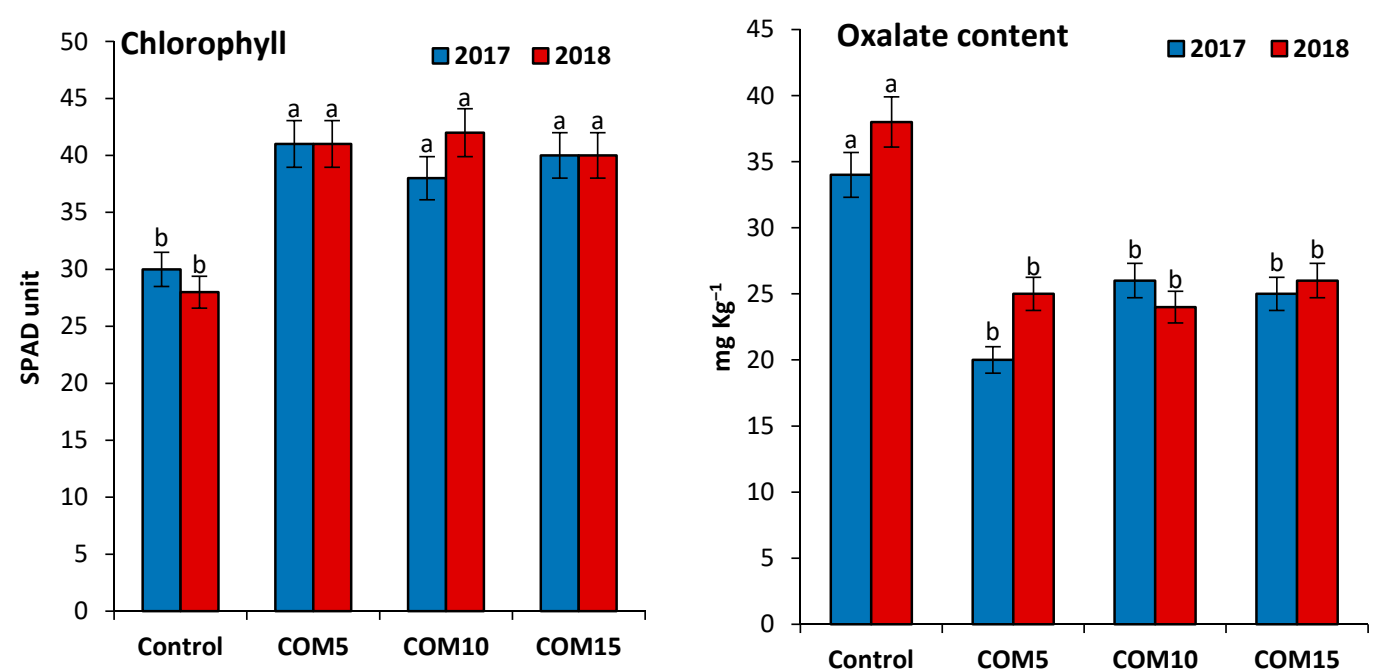

Figure 1. Effect of compost on chlorophyll and oxalate content in the leaves of river saltbush plants. $\mathrm{COM}_{5}=5 \mathrm{t}$ of compost $\mathrm{ha}^{-1}, \mathrm{COM}_{10}=10 \mathrm{t}$ of compost ha ${ }^{-1}$, and $\mathrm{COM}_{15}=15 \mathrm{t}$ of compost ha ${ }^{-1}$. Means $( \pm \mathrm{SD})$ symbolized by different letters refer to significant differences based on Duncan's test at $p<0.05$.

The activity of polyphenol oxidase (PPO) and catalase (CAT) was affected by the compost treatments, while the peroxidase (POX) activity was not affected by the treatments (Table 4). Compost significantly increased the activity of PPO and CAT in the two growing seasons compared with the control. $\mathrm{COM}_{5}, \mathrm{COM}_{10}$, and $\mathrm{COM}_{15}$ increased CAT by 14, 19, and $24 \%$ over the control in the first year, while these increases were 22,27 , and $22 \%$ in the second season. $\mathrm{COM}_{5}, \mathrm{COM}_{10}$, and $\mathrm{COM}_{15}$ increased the activity of PPO by 19, 19, and $22 \%$ over the control in the first season, while these increases were 31,19 , and $35 \%$ in the second growing season. 
Table 4. Effect of compost on antioxidant enzyme activities (unit $\mathrm{mg}^{-1}$ protein) in the leaves of river saltbush plants.

\begin{tabular}{|c|c|c|c|c|c|c|}
\hline \multicolumn{4}{|c|}{2017} & \multicolumn{3}{|c|}{2018} \\
\hline & CAT & PPO & POX & CAT & PPO & POX \\
\hline Control & $4.2 \pm 0.0^{b}$ & $2.7 \pm 0.0^{b}$ & $2.4 \pm 0.0^{a}$ & $4.1 \pm 0.0^{b}$ & $2.6 \pm 0.0^{b}$ & $2.7 \pm 0.0^{a}$ \\
\hline $\mathrm{COM}_{5}$ & $4.8 \pm 0.0^{\mathrm{a}}$ & $3.2 \pm 0.0^{\mathrm{a}}$ & $2.6 \pm 0.0^{a}$ & $5.0 \pm 0.0^{\mathrm{a}}$ & $3.4 \pm 0.0^{\mathrm{a}}$ & $2.4 \pm 0.0^{\mathrm{a}}$ \\
\hline $\mathrm{COM}_{10}$ & $5.0 \pm 0.0^{a}$ & $3.2 \pm 0.0^{\mathrm{a}}$ & $2.5 \pm 0.0^{\mathrm{a}}$ & $5.2 \pm 0.0^{\mathrm{a}}$ & $3.1 \pm 0.0^{\mathrm{a}}$ & $2.5 \pm 0.0^{\mathrm{a}}$ \\
\hline $\mathrm{COM}_{15}$ & $5.2 \pm 0.0^{a}$ & $3.3 \pm 0.0^{\mathrm{a}}$ & $2.4 \pm 0.0^{\mathrm{a}}$ & $5.0 \pm 0.0^{\mathrm{a}}$ & $3.5 \pm 0.0^{\mathrm{a}}$ & $2.6 \pm 0.0^{a}$ \\
\hline $\mathrm{F}_{\mathrm{t}}$ & $* *$ & $* *$ & $* * *$ & & & \\
\hline $\mathrm{F}_{\mathrm{y}}$ & ns & ns & ns & & & \\
\hline$F_{y \times t}$ & * & * & ns & & & \\
\hline
\end{tabular}

\subsection{Effect of Compost on Yield and Chemical Composition of River Saltbush}

The addition of compost significantly enhanced the forage yield of river saltbush plants in both studied years (Figure 2). River saltbush plant produced $9.23-15.60 \mathrm{t} \mathrm{ha}^{-1}$ of stems and 4.25-7.20 tha $\mathrm{t}^{-1}$ of leaves yearly. The addition of 5,10 , and $15 \mathrm{tha}^{-1}$ of compost $\left(\mathrm{COM}_{5}, \mathrm{COM}_{10}\right.$, and $\left.\mathrm{COM}_{15}\right)$ increased the stems yield by 35,49 , and $47 \%$ over the control in the first year, while these increases were 39,46 , and $49 \%$ in the second year. $\mathrm{COM}_{5}$, $\mathrm{COM}_{10}$, and $\mathrm{COM}_{15}$ increased the leaves yield by 28,40 , and $44 \%$ in the first year, while these increases were 26,32 , and $51 \%$ in the second year.
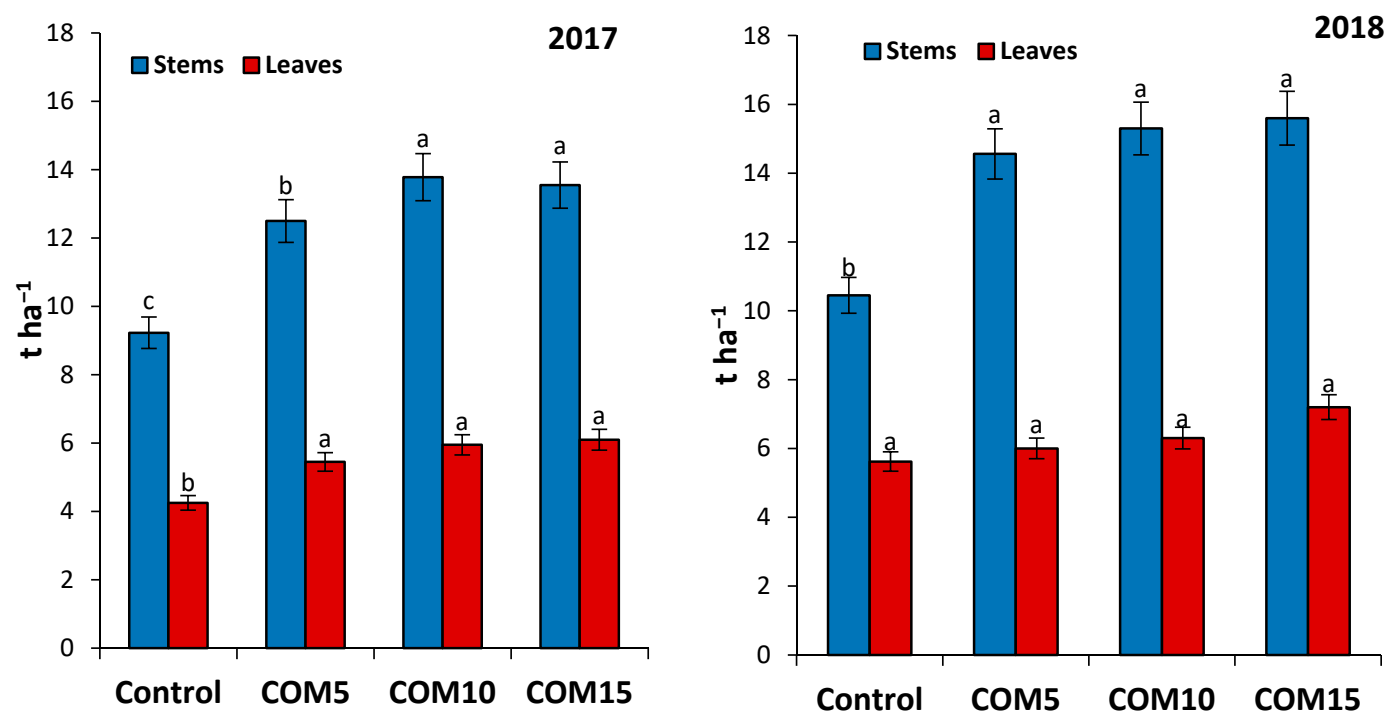

Figure 2. Effect of compost on the leaves and stems yield (tons ha ${ }^{-1}$ ) of river saltbush plants. $\mathrm{COM}_{5}=5 \mathrm{t}$ of compost ha ${ }^{-1}$, $\mathrm{COM}_{10}=10 \mathrm{t}$ of compost ha ${ }^{-1}$, and $\mathrm{COM}_{15}=15 \mathrm{t}$ of compost ha ${ }^{-1}$. Means $( \pm \mathrm{SD})$ symbolized by different letters refer to significant differences based on Duncan's test at $p<0$.

Composting the increased dry matter and crude protein in the first and second years (Table 5). Moisture content, organic matter, and crude protein were increased significantly due to compost application. In general, the dry matter and crude protein in the leaves were higher than in the stems. The crude protein (CP) ranged between $48-70 \mathrm{mg} \mathrm{kg}^{-1}$ in the stems and between $160-240 \mathrm{mg} \mathrm{kg}^{-1}$ in the leaves. $\mathrm{COM}_{5}, \mathrm{COM}_{10}$, and $\mathrm{COM}_{15}$ increased $\mathrm{CP}$ by 38,31 , and $25 \%$ in the first year, while these increases were 15,20 , and $10 \%$ in the second year. 
Table 5. Effect of compost treatments on the chemical composition of leaves and stems of river saltbush plants $\left(\mathrm{g} \mathrm{kg}^{-1}\right)$.

\begin{tabular}{|c|c|c|c|c|c|c|c|c|c|c|c|c|}
\hline & \multicolumn{6}{|c|}{2017} & \multicolumn{6}{|c|}{2018} \\
\hline & MC & DM & OM & $\mathrm{CP}$ & Fat & $\mathrm{CF}$ & MC & DM & OM & $\mathrm{CP}$ & Fat & $\mathrm{CF}$ \\
\hline & \multicolumn{12}{|c|}{ Leaves } \\
\hline Control & $730 \pm 35^{b}$ & $200 \pm 8^{\mathrm{a}}$ & $780 \pm 33 \mathrm{~b}$ & $160 \pm 11^{b}$ & $12 \pm 1.2^{a}$ & $210 \pm 9 \mathrm{a}$ & $730 \pm 40^{\mathrm{b}}$ & $250 \pm 6^{\mathrm{a}}$ & $700 \pm 28 \mathrm{~b}$ & $200 \pm 9 c$ & $10 \pm 1.1^{\mathrm{a}}$ & $120 \pm 6^{a}$ \\
\hline $\mathrm{COM}_{5}$ & $800 \pm 40^{\mathrm{a}}$ & $210 \pm 7^{a}$ & $810 \pm 28 \mathrm{a}$ & $220 \pm 8^{\mathrm{a}}$ & $14 \pm 1.0^{\mathrm{a}}$ & $100 \pm 9 b$ & $860 \pm 37$ a & $240 \pm 5^{a}$ & $810 \pm 25^{a}$ & $230 \pm 8$ ab & $12 \pm 1.1^{\mathrm{a}}$ & $100 \pm 7 \mathrm{~b}$ \\
\hline $\mathrm{COM}_{10}$ & $850 \pm 32^{\mathrm{a}}$ & $210 \pm 8^{\mathrm{a}}$ & $830 \pm 25^{a}$ & $210 \pm 7^{a}$ & $14 \pm 1.0^{\mathrm{a}}$ & $120 \pm 8 \mathrm{~b}$ & $850 \pm 38$ a & $270 \pm 8^{\mathrm{a}}$ & $850 \pm 22 \mathrm{a}$ & $240 \pm 5^{a}$ & $13 \pm 1.3^{\mathrm{a}}$ & $110 \pm 8^{b}$ \\
\hline $\mathrm{COM}_{15}$ & $860 \pm 40^{a}$ & $200 \pm 8^{\mathrm{a}}$ & $810 \pm 40^{\mathrm{a}}$ & $200 \pm 8^{a}$ & $12 \pm 1.1^{a}$ & $100 \pm 7^{b}$ & $880 \pm 32^{a}$ & $270 \pm 7^{a}$ & $820 \pm 30^{a}$ & $220 \pm 7 \mathrm{~b}$ & $10 \pm 1.3^{\mathrm{a}}$ & $105 \pm 5^{b}$ \\
\hline $\mathrm{F}_{\mathrm{t}}$ & $* *$ & $* *$ & $* * *$ & $* *$ & ns & $* * *$ & & & & & & \\
\hline $\mathrm{F}_{\mathrm{y}}$ & ns & ns & ns & ns & ns & ns & & & & & & \\
\hline \multirow[t]{2}{*}{$F_{y \times t}$} & * & $*$ & ns & ns & ns & * & & & & & & \\
\hline & \multicolumn{12}{|c|}{ Stems } \\
\hline Control & $520 \pm 22 b$ & $480 \pm 15^{\mathrm{a}}$ & $890 \pm 55^{b}$ & $50 \pm 3^{a}$ & $11 \pm 1.4^{\mathrm{a}}$ & $270 \pm 8^{a}$ & $590 \pm 24^{a}$ & $450 \pm 15^{\mathrm{a}}$ & $920 \pm 50^{a}$ & $60 \pm 4^{\mathrm{a}}$ & $10 \pm 1.2^{\mathrm{a}}$ & $220 \pm 8^{a}$ \\
\hline $\mathrm{COM}_{5}$ & $620 \pm 18^{a}$ & $480 \pm 18^{a}$ & $910 \pm 65$ a & $50 \pm 2^{\mathrm{a}}$ & $12 \pm 1.2^{\mathrm{a}}$ & $160 \pm 9 \mathrm{~b}$ & $560 \pm 18^{a}$ & $470 \pm 17^{\mathrm{a}}$ & $910 \pm 58 \mathrm{~b}$ & $70 \pm 3^{a}$ & $12 \pm 1.1^{\mathrm{a}}$ & $140 \pm 5^{b}$ \\
\hline $\mathrm{COM}_{10}$ & $615 \pm 25^{\mathrm{a}}$ & $480 \pm 20^{\mathrm{a}}$ & $900 \pm 50^{a}$ & $48 \pm 3^{a}$ & $11 \pm 1.0^{\mathrm{a}}$ & $130 \pm 8^{b}$ & $500 \pm 27 \mathrm{~b}$ & $500 \pm 20^{a}$ & $890 \pm 60 \mathrm{~d}$ & $50 \pm 2^{\mathrm{a}}$ & $11 \pm 1.0^{\mathrm{a}}$ & $150 \pm 9 \mathrm{~b}$ \\
\hline $\mathrm{COM}_{15}$ & $650 \pm 26^{\mathrm{a}}$ & $450 \pm 15^{\mathrm{a}}$ & $910 \pm 58^{a}$ & $50 \pm 2^{a}$ & $11 \pm 1.1^{\mathrm{a}}$ & $140 \pm 7 \mathrm{~b}$ & $570 \pm 22^{a}$ & $490 \pm 19^{\mathrm{a}}$ & $900 \pm 62 \mathrm{c}$ & $70 \pm 4^{\mathrm{a}}$ & $12 \pm 1.4^{\mathrm{a}}$ & $160 \pm 9^{b}$ \\
\hline $\mathrm{F}_{\mathrm{t}}$ & $* *$ & $* *$ & $*$ & ns & ns & $* * *$ & & & & & & \\
\hline $\mathrm{F}_{\mathrm{y}}$ & ns & * & ns & ns & ns & * & & & & & & \\
\hline$F_{y \times t}$ & ns & ns & ns & ns & ns & ns & & & & & & \\
\hline
\end{tabular}

$\mathrm{COM}_{5}=5 \mathrm{t}$ of compost ha ${ }^{-1}, \mathrm{COM}_{10}=10 \mathrm{t}$ of compost ha ${ }^{-1}$, and $\mathrm{COM}_{15}=15 \mathrm{t}$ of compost ha ${ }^{-1}, \mathrm{MC}=$ moisture content, DM $=$ dry matter, $\mathrm{OM}=$ organic matter, $\mathrm{CP}=$ crude protein, $\mathrm{CF}=$ crude fiber. ${ }^{*} p<0.05,{ }^{* *} p<0.01$, ${ }^{* * *} p<0.001$, ns: non-significant. Means $( \pm \mathrm{SD})$ denoted by the same letter refers to non-significant differences based on Duncan's test at $p<0.05 . \mathrm{F}_{\mathrm{t}}, \mathrm{F}_{\mathrm{y}}$, and $\mathrm{F}_{\mathrm{y} \times \mathrm{t}}$ refer to the $\mathrm{F}$ value of the treatments, years, and the interaction of treatments and years.

\section{Discussion}

Halophyte plants tolerate high concentrations of salt, whether in soil or irrigation water, but saline leads to reduced productivity and quality $[5,22]$. Soil salinity inhibits plant growth through osmotic effects, specific-ion toxicity, and/or shortage and disorders of some nutrients [33-35]. The findings of the current study show that the role of compost addition increased the salt tolerance of river saltbush plants grown in the sandy loam saline soils, which had a salinity of $15 \mathrm{dS} \mathrm{m} \mathrm{m}^{-1}$. Compost improved the dry matter and crude protein and the forage yield of river saltbush. Compost enhances the salt tolerance by increasing the soil quality, nutrient uptake, reducing the adsorb of toxic elements, e.g., $\mathrm{Na}^{+}$and $\mathrm{Cl}^{-}$, and improving the physiological defense of the plants $[2,14,15,36]$.

Our study clearly indicated that the compost addition had a positive role in increasing the essential plant nutrients uptake and reducing the uptake of $\mathrm{Na}^{+}$. The increases in nutrients uptake, due to compost addition, are may be due to the improvement of soil quality [14]. Organic matter in the applied compost may lead to an improvement in aeration and consequently an optimal root growth, thereby an increase in the nutrient uptake and growth $[14,18,37]$. K The application of composted organic materials significantly enhanced the N, P, and uptake by corn plants compared to the control, and the increase was proportional with the addition rates [18]. Compost is rich with organic materials and has a high cation exchange capacity which may reduce Na uptake [16]. Organic amendment added to saline-irrigated basil plants (Ocimum basilicum) minimized $\mathrm{Na}^{+}$adsorb by $47 \%$ compared to the untreated plants [16]. Compost may absorb the soluble salts from the soil solution and reduce their availability for plant uptake [14,16,38-41].

Application of compost to saline soil enhanced the photosynthesis process and increased the chlorophyll in the leaves of river saltbush plants. The increase in chlorophyll might be due to increasing plant growth and minimizing salt stress $[14,16]$. Under salt stress, halophyte plants tend to reduce the synthesis of chlorophyll and increase some osmotic regulations, e.g., oxalic acid [42]. It is clear that compost in the current study reduced the negative effects of salts by activating the antioxidant enzyme defense. The liberation of the plant from salt stress led to directing the plant energy towards the synthesis of chlorophyll and growth, and thus, increased the dry matter production and the crude protein and dry matter of the resulting fodder crop. The addition of soil organic amendments increased the activity of antioxidant enzymes in tomato and maize plants [17,20]. The addition of compost improved plant growth and alleviated salt stress by increasing the uptake of macro- and micro-nutrients, which are released through the decomposition of organic matter $[43,44]$. Moreover, the increase in the growth could be due to the compostability in increasing the water holding capacity [9,45-47]. 
River saltbush plants cultivated on saline soils $\left(15 \mathrm{dS} \mathrm{m}^{-1}\right)$ produce 13.48 to $22.80 \mathrm{t} \mathrm{ha}^{-1}$ of dry matter yearly. Despite the high levels of salinity, halophyte plants can give high dry matter (15-22 $\mathrm{t}$ dry matter ha ${ }^{-1}$ year $^{-1}$ ), which means great hope in supplying forage cultivation for livestock [6-8]. The addition of $15 \mathrm{tha}^{-1}$ of compost caused remarkable increases in the yield and crude protein and dry matter. Similar results for the positive impacts of compost in enhancing the yield and crude protein of the halophyte plants were found [9,48-52].

\section{Conclusions}

Arid climatic conditions cause the formation of saline soils that are not suitable for the production of traditional crops. In this two-year field study, the saline soil had a salinity of $15 \mathrm{dS} \mathrm{m}^{-1}$, and was used in the production of river saltbush - a halophytic forage plant. Compost was added to the plants to improve the soil quality and enhance growth. The findings of the current study revealed the role of compost in increasing the productivity and quality of river saltbush plants grown in saline soil. River saltbush plants produced $18 \mathrm{tha}^{-1}$ of dry matter yearly when cultivated in saline soils. The produced forage material is valuable as animal feed, due to its high crude protein. The obtained results represent a promising opportunity to utilize saline land in arid regions to produce animal fodder. Compost should be added to halophyte plants to lessen the adverse effects of salts on the quality of the forage material. Compost assists river saltbush in overcoming the negative impacts of salinity through enhancing the nutrient uptake, photosynthesis process, and activity of antioxidant enzymes. Considering that the addition of compost increased crude protein and reduced crude fiber, then we can speculate that also the nutritional value of the forage increased. Several field studies must be done to find out the best agricultural practices that improve the quality and productivity of the halophyte plants under saline conditions.

Author Contributions: Conceptualization A.M. and J.L.; methodology, M.A.E. and J.L.; software, E.F.A.; validation, M.A.E., J.L. and E.F.A.; data curation, M.A.E.; writing-original draft preparation, M.A.E.; writing—review and editing, O.H.M.I. and A.M.; visualization, E.F.A.; supervision, M.A.E.; project administration A.M. All authors have read and agreed to the published version of the manuscript.

Funding: The authors are thankful to Taif University Researchers Supporting Project number (TURSP2020/110), Taif University, Saudi Arabia, for the financial support and research facilities. National Natural Science Foundation of China (32072608).

Institutional Review Board Statement: Not applicable.

Informed Consent Statement: Not applicable.

Acknowledgments: The authors are thankful to Taif University Researchers Supporting Project number (TURSP-2020/110), Taif University, Taif, Saudi Arabia, for the financial support and research facilities. The authors are thankful also to National Natural Science Foundation of China (32072608).

Conflicts of Interest: There were no conflict of interest from the authors.

\section{References}

1. Wicke, B.; Smeets, E.; Dornburg, V.; Vashev, B.; Gaiser, T.; Turkenburg, W.; Faaij, A. The global technical and economic potential of bioenergy from salt-affected soils. Energy Environ. Sci. 2011, 4, 2669-2681. [CrossRef]

2. Gunarathne, V.; Senadeera, A.; Gunarathne, U.; Biswas, J.K.; Almaroai, Y.A.; Vithanage, M. Potential of biochar and organic amendments for reclamation of coastal acidic-salt affected soil. Biochar 2020, 2, 107-120. [CrossRef]

3. Shrivastava, P.; Kumar, R. Soil salinity: A serious environmental issue and plant growth promoting bacteria as one of the tools for its alleviation. Saudi J. Biol. Sci. 2015, 22, 123-131. [CrossRef] [PubMed]

4. Houshmand, S.; Arzani, A.; Maibody, S.A.M.; Feizi, M. Evaluation of salt-tolerant genotypes of durum wheat derived from in vitro and field experiments. Field Crop. Res. 2005, 91, 345-354. [CrossRef]

5. Yuan, F.; Guo, J.; Shabala, S.; Wang, B. Reproductive physiology of halophytes: Current standing. Front. Plant Sci. 2019, 9, 1954. [CrossRef] 
6. Masters, D.G.; Norman, H.C. Genetic and Environmental Management of Halophytes for Improved Livestock Production. In Halophytes for Food Security in Dry Lands; Academic Press, Elsevier Inc.: Amsterdam, The Netherlands, 2016 ; pp. $243-257$.

7. Soliz, D.; Glenn, E.P.; Seaman, R.; Yoklilc, M.; Nelson, S.; Brown, P. Water consumption, irrigation efficiency and nutritional value of Atriplex lentiformis grown on reverse osmosis brine in a desert irrigation district. Agric. Ecosyst. Environ. 2011, 63, 137-148. [CrossRef]

8. Walker, D.J.; Lutts, S.; Sánchez-García, M.; Correal, E. Review: Atriplex halimus L.: Its biology and uses. J. Arid Environ. 2014, 100, 111-121. [CrossRef]

9. Eissa, M.A.; Ahmedand, E.M.; Reichman, S. Production of the forage halophyte Atriplex amnicola in metal-contaminated soils. Soil Use Manag. 2016, 32, 350-356. [CrossRef]

10. El-Hack, M.E.A.; Samak, D.H.; Noreldin, A.E.; Arif, M.; Yaqoob, H.S.; Swelum, A.A. Towards saving freshwater: Halophytes as unconventional feedstuffs in livestock feed: A review. Environ. Sci. Pollut. Res. 2018, 25, 14397-14406. [CrossRef]

11. Swingle, R.; Glenn, E.P.; Squires, V. Growth performance of lambs fed mixed diets containing halophyte ingredients. Anim. Feed Sci. Technol. 1996, 63, 137-148. [CrossRef]

12. Dann, H.M.; Grant, R.J.; Cotanch, K.W.; Thomas, E.D.; Ballard, C.S.; Rice, R. Comparison of brown midrib sorghum-sudangrass with corn silage on lactational performance and nutrient digestibility in Holstein dairy cows. J. Dairy Sci. 2008, 91, 663-672. [CrossRef] [PubMed]

13. Hashim, M.A.; Siam, N.; Al-Dosari, A.; Asl-Gaadi, K.A.; Patil, V.C.; Tola, E.H.M.; Rangaswamy, M.; Samdani, M.S. Determination of water requirement and crop water productivity of crops grown in the Makah region of Saudi Arabia. Aust. J. Basic Appl. Sci. 2012, 6, 196-206.

14. Rekaby, S.A.; Awad, M.Y.; Hegab, S.A.; Eissa, M.A. Effect of some organic amendments on barley plants under saline condition. J. Plant Nutr. 2020, 43, 1840-1851. [CrossRef]

15. Aher, S.B.; Lakaria, B.L.; Singh, A.B.; Kaleshananda, S.; Ramana, S.; Ramesh, K.; Thakur, J.K.; Rajput, P.S.; Yashona, D.S. Effect of organic sources of nutrients on performance of soybean (Glycine max). Indian J. Agric. Sci. 2019, 89, 35-39.

16. Ding, Z.; Zhou, Z.; Lin, X.; Zhao, F.; Wang, B.; Lin, F.; Ge, Y.; Eissa, M.A. Biochar impacts on $\mathrm{NH}_{3}$-volatilization kinetics and growth of sweet basil (Ocimum basilicum L.) under saline conditions. Ind. Crop. Prod. 2020, 157, 11290. [CrossRef]

17. Rady, A.A. A novel organo-mineral fertilizer can mitigate salinity stress effects for tomato production on reclaimed saline soil. $S$. Afr. J. Bot. 2012, 81, 8-14. [CrossRef]

18. Geng, Y.; Cao, G.; Wang, L.; Wang, S. Effects of equal chemical fertilizer substitutions with organic manure on yield, dry matter, and nitrogen uptake of spring maize and soil nitrogen distribution. PLoS ONE 2019, 14, e0219512. [CrossRef]

19. Mahmoud, E.; Ibrahim, M.; Ali, N.; Ali, H. Effect of biochar and compost amendments on soil biochemical properties and dry weight of canola plant grown in soil contaminated with heavy metals. Commun. Soil Sci. Plant Anal. 2020, 51, $1561-1571$. [CrossRef]

20. Shahkolaie, S.S.; Baranimotlagh, M.; Dordipour, E.; Khormali, F. Effects of inorganic and organic amendments on physiological parameters and antioxidant enzymes activities in Zea mays L. from a cadmium-contaminated calcareous soil. S. Afr. J. Bot. 2020, 128, 132-140. [CrossRef]

21. Norman, H.C.; Masters, D.G.; Barrett-Lennard, E.G. Halophytes as forages in saline landscapes: Interactions between plant genotype and environment change their feeding value to ruminants. Environ. Exp. Bot. 2013, 92, 96-109. [CrossRef]

22. Waldron, B.L.; Sagers, J.K.; Peel, M.D.; Rigby, C.W.; Bugbee, B.; Creech, J.E. Salinity reduces the forage quality of forage kochia: A halophytic Chenopodiaceae shrub. Rangel. Ecol. Manag. 2020, 73, 384-393. [CrossRef]

23. Chhabra, R. Classification of salt-affected soils. Arid Land Res. Manag. 2004, 19, 61-79. [CrossRef]

24. Soil Survey Staff 2016. Keys to Soil Taxonomy, 11th ed.; USDA-Natural Resources Conservation Services: Washington, DC, USA, 1997.

25. Burt, R. Soil Survey Laboratory Methods Manual; Soil Survey Investigations Report No. 42, Version 4.0; Natural Resources Conservation Service, United States Department of Agriculture: Lincoln, NE, USA, 2004.

26. Parkinson, J.A.; Allen, S.E. A wet oxidation procedure suitable for the determination of nitrogen and mineral nutrients in biological material. Comm. Soil Sci. Plant Anal. 1975, 6, 1-11. [CrossRef]

27. Zaklouta, M.; Hilali, M.; Nefzaoui, A.; Haylani, M. Animal Nutrition and Product Quality Laboratory Manual; ICARDA: Aleppo, Syria, 2011; Volume viii, p. 92.

28. Chandlee, J.M.; Scandalios, J.G. Analysis of variants affecting the catalase development program in maize scutellum. Theor. Appl. Genet. 1984, 69, 71-77. [CrossRef] [PubMed]

29. Kumar, K.B.; Khan, P.A. Peroxidase and polyphenol oxidase in excised ragi Eleusine coracana (V. PR 202) leaves during senescence. Indian J. Exp. Bot. 1982, 20, 412-416.

30. Naik, V.V.; Patil, N.S.; Aparadh, V.T.; Karadge, B.A. Methodology in determination of oxalic acid in plant tissue: A comparative approach. J. Glob. Trends Pharm. Sci. 2014, 5, 1662-1672.

31. Ball, D.F. Loss-on-ignition as an estimate of organic matter and organic carbon in non-calcareous soils. J. Soil Sci. 1964, 15, 84-92. [CrossRef]

32. Michigan State University. MSTAT-C Micro-Computer Statistical Program; Version 2; Michigan State University: East Lansing, MI, USA, 1983. 
33. Reda, M.; Migocka, M.; Kłobus, G. Effect of short-term salinity on the nitrate reductase activity in cucumber roots. Plant Sci. 2011, 180, 783-788. [CrossRef]

34. Syeed, S.; Anjum, N.A.; Nazar, R.; Iqbal, N.; Masood, A.; Khan, N.A. Salicylic acid-mediated changes in photosynthesis, nutrients content and antioxidant metabolism in two mustard (Brassica juncea L.) cultivars differing in salt tolerance. Acta Physiol. Plant. 2011, 86, 33-877. [CrossRef]

35. Silvertooth, C.J. Fertigation in arid regions and saline soils. In Proceedings of the IPINATESC-CAU-CAAS International Symposium on Fertigation, Beijing, China, 1 September 2005; International Potash Institute: Horgen, Switzerland, 2005; pp. 171-177.

36. Ding, Z.; Ali, E.F.; Elmahdy, A.M.; Ragab, K.E.; Seleiman, M.F.; Kheir, A.M.S. Modeling the combined impacts of deficit irrigation, rising temperature and compost application on wheat yield and water productivity. Agric. Water Manag. 2020, $244,106626$. [CrossRef]

37. Babalola, O.A.; Adesodun, J.K.; Olasantan, F.O.; Adekunle, A.F. Responses of some soil biological, chemical and physical properties to short-term compost amendment. Int. J. Soil Sci. 2012, 7, 28-38. [CrossRef]

38. Eissa, M.A. Phosphate and organic amendments for safe production of okra from metal-contaminated soils. Agron. J. 2016, 108, 540-547. [CrossRef]

39. Abou-Zaid, E.A.; Eissa, M.A. Thompson seedless grapevines growth and quality as affected by glutamic acid, vitamin b, and algae. J. Soil Sci. Plant Nutr. 2019, 19, 725-733. [CrossRef]

40. Ali, A.M.; Awad, M.Y.; Hegab, S.A.; Gawad, A.M.A.E.; Eissa, M.A. Effect of potassium solubilizing bacteria (Bacillus cereus) on growth and yield of potato. J. Plant Nutr. 2021, 44, 411-420. [CrossRef]

41. Huang, M.; Zhang, Z.; Zhai, Y.; Lu, P.; Zhu, C. Effect of straw biochar on soil properties and wheat production under saline water irrigation. Agronomy 2019, 9, 457. [CrossRef]

42. Eissa, M.A.; Abeed, A.H. Growth and biochemical changes in quail bush (Atriplex lentiformis (Torr.) S.Wats) under Cd stress. Environ. Sci. Pollut. Res. 2019, 26, 628-635. [CrossRef]

43. Drake, J.A.; Cavagnaro, T.R.; Cunningham, S.C.; Jackson, W.R.; Patti, A.F. Does biochar improve establishment of tree seedlings in saline sodic soils? Land Degrad. Dev. 2016, 27, 52-59. [CrossRef]

44. Kim, H.; Jeong, H.; Jeon, J.; Bae, S. Effects of irrigation with saline water on crop growth and yield in greenhouse cultivation. Water 2016, 8, 127. [CrossRef]

45. Silber, A.; Levkovitch, I.; Graber, E.R. pH dependent mineral release and surface properties of corn straw biochar: Agronomic implications. Environ. Sci. Technol. 2010, 44, 9318-9323. [CrossRef]

46. Eissa, M.A.; Nafady, M.H.; Ragheb, H.M.; Attia, K.K. Effect of soil moisture and forms of phosphorus fertilizers on corn production under sandy calcareous soil. World Appl. Sci. J. 2013, 26, 540-547.

47. Al-Sayed, H.; Hegab, S.A.; Youssef, M.; Khalafalla, M.; Almaroai, Y.A.; Ding, Z.; Eissa, M.A. Evaluation of quality and growth of roselle (Hibiscus sabdariffa L.) as affected by bio-fertilizers. J. Plant Nutr. 2020, 43, 1025-1035. [CrossRef]

48. Eissa, M.A. Performance of river saltbush (Atriplex amnicola) grown on contaminated soils as affected by organic fertilization. World Appl. Sci. J. 2014, 30, 1877-1881.

49. Eissa, M.A. Phytoextraction of nickel, lead and cadmium from metal contaminated soils using different field crops and EDTA. World Appl. Sci. J. 2014, 32, 1045-1052.

50. Eissa, M.A. Effect of compost and biochar on heavy metals phytostabilization by the halophytic plant old man saltbush [Atriplex nummularia Lindl]. Soil Sediment Contam. Int. J. 2019, 28, 135-147. [CrossRef]

51. Eissa, M.A.; Almaroai, Y.A. Phytoremediation capacity of some forage plants grown on a metals-contaminated soil. Soil Sediment Contam. Int. J. 2019, 28, 569-581. [CrossRef]

52. Eissa, M.A. Impact of compost on metals phytostabilization potential of two halophytes species. Int. J. Phytoremediat. 2015, 17, 662-668. [CrossRef] 